Bond University

Research Repository

\title{
Increased amino acid turnover and myofibrillar protein breakdown in advanced cancer are associated with muscle weakness and impaired physical function
}

Van der Meij, Barbara S; Deutz, Nicolaas E P; Rodriguez, Ramon E.; Engelen, Marielle P.

Published in:

Clinical Nutrition

DOI:

10.1016/j.clnu.2018.10.022

Licence:

CC BY-NC-ND

Link to output in Bond University research repository.

Recommended citation(APA):

Van der Meij, B. S., Deutz, N. E. P., Rodriguez, R. E., \& Engelen, M. P. (2019). Increased amino acid turnover and myofibrillar protein breakdown in advanced cancer are associated with muscle weakness and impaired physical function. Clinical Nutrition, 38(5), 2399-2407. https://doi.org/10.1016/j.clnu.2018.10.022

\section{General rights}

Copyright and moral rights for the publications made accessible in the public portal are retained by the authors and/or other copyright owners and it is a condition of accessing publications that users recognise and abide by the legal requirements associated with these rights.

For more information, or if you believe that this document breaches copyright, please contact the Bond University research repository coordinator. 
Original article

\title{
Increased amino acid turnover and myofibrillar protein breakdown in advanced cancer are associated with muscle weakness and impaired physical function
}

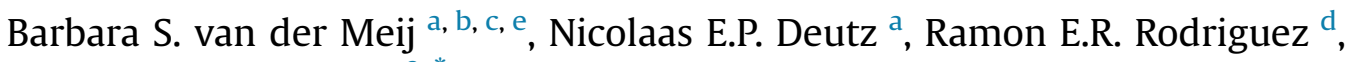 \\ Mariëlle P.K.J. Engelen a, * \\ ${ }^{a}$ Center for Translational Research in Aging \& Longevity, Dept. Health and Kinesiology, Texas A\&M University, 675 John Kimbrough Blvd, College Station, TX \\ 77843-4253, USA \\ ${ }^{\mathrm{b}}$ Bond Institute of Health and Sport, Faculty of Health Sciences \& Medicine, Gold Coast, QLD, Australia \\ ${ }^{\mathrm{C}}$ Nutrition and Dietetics, Mater Group, Brisbane, QLD, Australia \\ d Div. Hematology/Oncology, Baylor Scott and White Medical Center, College Station, TX, USA \\ e Mater Research Institute, University of Queensland, Brisbane, OLD, Australia
}

\section{A R T I C L E I N F O}

Article history:

Received 23 May 2018

Accepted 26 October 2018

\section{Keywords:}

Cancer

Chemotherapy

Protein metabolism

Muscle strength

Amino acids

\begin{abstract}
S U M M A R Y
Background \& aims: Muscle wasting in cancer negatively affects physical function and quality of life. This study investigates amino acid metabolism and the association with muscle mass and function in patients with cancer

Methods: In 16 patients with advanced cancer undergoing chemotherapy and 16 healthy controls, we administered an intravenous pulse and prime of stable amino acid tracers. We took blood samples to measure the Rate of appearance ( $\mathrm{Ra}$ ), whole body production (WBP), clearance $(\mathrm{Cl})$, and post absorptive whole body net protein breakdown (WBnetPB). Plasma amino acid concentrations and enrichments were analysed by LC-MS/MS. We assessed muscle mass, handgrip/leg/respiratory muscle strength and reported physical activity, quality of life, and physical function.

Results: Muscle strength was lower in cancer patients than in healthy controls. Total and limb muscle mass, reported physical activity and WBnetPB were comparable. WBP and $\mathrm{Cl}$ of tau-methylhistidine, leucine, glutamine and taurine were higher in cancer patients as well as glycine $\mathrm{Cl}$. Amino acid metabolism was correlated with low muscle mass, strength, physical function and quality of life.

Conclusions: Myofibrillar protein breakdown and production of amino acids involved in muscle contractility are up regulated in patients with cancer undergoing chemotherapy and related to muscle weakness and reduced physical outcomes.
\end{abstract}

(C) 2018 Elsevier Ltd and European Society for Clinical Nutrition and Metabolism. All rights reserved.

\section{Introduction}

An important indicator of health, well-being and treatment outcome in patients with cancer is the amount of muscle mass and function in the body. A relatively low amount of muscle mass has been observed in $20 \%-70 \%$ of people with cancer [1] and is associated with physical impairment, impaired quality of life [2], treatment toxicity, and a shorter survival $[3,4]$. A loss of muscle mass is called 'sarcopenia' and is usually associated with ageing [1]. Muscle loss associated with chronic diseases, including cancer, is

\footnotetext{
* Corresponding author.

E-mail address: mpkj.engelen@ctral.org (M.P.K.J. Engelen).
}

often referred to as 'secondary sarcopenia' [1]. Besides secondary sarcopenia, skeletal muscle weakness is frequently observed in stable patients with advanced cancer $[5,6]$ and during or after anticancer treatment $[6,7]$. Previous studies showed that infusion of the chemotherapy drug doxorubicin in an animal model caused permanent muscle necrosis, loss of muscle mass, altered myofilament structure, and depressed force [8], while in patients with lymphoma, leukaemia and breast cancer doxorubicin treatment resulted in muscle weakness and fatigue [9].

Over the years, many studies have focused on the metabolic disturbances underlying muscle wasting and the role of the enhanced chronic systemic inflammatory response in cancer $[10,11]$. For instance, the presence of a tumour is related to metabolic 
alterations initiated by factors such as increased adrenal activity and glucocorticoid levels, muscle-specific activation of nuclear factor kappa B (NF-kB), activation of the ubiquitin-dependent proteasome pathway, release of pro-inflammatory cytokines as a result of systemic inflammation, and diminished glucose tolerance. These factors increase basal metabolic rate, inhibit adipocyte and skeletal myocyte differentiation, and reduce food intake [10]. In addition, chemotherapy and radiotherapy can further reduce food intake and alter metabolism by causing nausea, vomiting, dysgeusia and fatigue, further contributing to weight loss and muscle wasting [12,13].

Altered whole body rate of appearance of amino acids has been reported in patients with advanced cancer [14,15]. In addition, abnormal plasma free amino acid profiles that differ among cancer stages, tumour types and degrees of weight loss have been reported $[16,17]$. Studies examining muscle metabolism in patients with cancer found inconsistent results as skeletal muscle protein fractional synthesis rate was found to be unchanged or reduced in patients with cancer $[10,18]$. A recent study examining muscle myofibrillar protein synthesis found comparable values between healthy participants and weight-losing patients with gastrointestinal cancer [19], suggesting that muscle wasting is likely more related to increased muscle protein breakdown [18]. We have recently shown that muscle weakness in cancer cannot be fully explained by the presence of muscle loss alone: with the upcoming rates of overweight and obesity, preserved values for muscle mass and presence of a high body fat are more common in patients with cancer [20]. Disturbances in protein metabolism are observed in many cancer types, even when cachexia or weight loss is absent [11,21]. Also, chemotherapeutic agents like methotrexate (MTX) and 5-fluorouracil (5-FU) decrease nitrogen balance in tumourbearing rats [22]. In children with acute leukaemia receiving MTX treatment, increased rates of whole-body protein turnover and synthesis were observed [23]. Thus there are clear changes in whole body protein metabolism and muscle metabolism in cancer patients undergoing chemotherapy. So far, it was unclear whether these changes relate to the metabolism of other amino acids.

In the present study, we used a targeted metabolic flux approach to examine the (protein and amino acid) metabolic characteristics of a well-described heterogeneous group of advanced stage cancer patients undergoing chemotherapy using a combined pulse and primed-constant infusion of multiple stable isotopes. The effect of cancer-induced altered metabolism on muscle mass and contractility was evaluated by measuring amino acids markers for protein breakdown including phenylalanine, taurine, methylhistidine, glutamine, taurine and glycine.

\section{Materials and methods}

\subsection{Subjects}

The study population included 16 patients with advanced cancer and 16 gender- and age-matched healthy subjects from the MEDIT trial (MEtabolism of Disease with Isotope Tracers) (Table 2) [24]. Recruitment of patients with cancer took place through oncologist referral from the Scott \& White Hematology/Oncology Clinic, St Joseph Regional Cancer Center, Aggieland Cancer Treatment Center and MD Anderson Cancer Center (College Station/ Bryan/Houston, TX, USA). All patients with cancer had solid tumours and were scheduled for chemotherapy or chemoradiotherapy, able to sign informed consent, and 18 years or older. Control subjects were healthy males or females according to the investigator's or appointed staff's judgment, 18 years or older, and did not have a diagnosis of cancer. Cancer and healthy subjects with previous pre-existent metabolic or renal diseases or untreated metabolic diseases including liver or renal disease were excluded from participation. The study was performed in accordance with the Declaration of Helsinki. Written informed consent was obtained from all subjects and the study was approved by the Institutional Review Board of Texas A\&M University (reference number: 20120504) and the study was registered in the Clinical Trial Registration (reference number: NCT01871350). All subjects were studied at the Clinical Research Unit of the Center for Translational Research on Aging and Longevity, Texas A\&M University. The study procedures were identical in both groups and the study day lasted approximately 6 h (Supplementary Fig. 1).

\subsection{Anthropometrics and body composition}

Body weight and height were measured by a digital beam scale and stadiometer, respectively.

Furthermore, whole body, trunk and extremity (arms and legs) fat mass (FM) and fat-free mass (FFM) were obtained from all subjects while in supine position by dual-energy X-ray absorptiometry (DXA) (Hologic QDR 4500/Version 12.7.3.1 (Bedford, MA, USA)). Anthropometric and body composition measures were standardized for height $\left(\mathrm{kg} / \mathrm{m}^{2}\right)$, as suggested by VanItallie [25] to obtain BMI, FFM index (FFMI), FM index (FMI) and appendicular skeletal muscle index (ASMI).

\subsection{Muscle function}

Respiratory and skeletal muscle function was assessed in all subjects. Maximal expiratory pressure (MEP) and maximal inspiratory pressure (MIP) were assessed by determining the maximal value of at least 3 reliable attempts using a hand-held mouth pressure device (Micro Respiratory Pressure Meter (RPM) (Vernier, Beaverton, OR)) [26].

Following pre-test stretching and warm-up, the peak leg force during one leg reciprocal extensions (at $60^{\circ} / \mathrm{sec}$ ) and the peak handgrip force that the subject was able to generate out of 3 reproducible repetitions, with $1 \mathrm{~min}$ of rest between each attempt, were used as marker of leg strength and handgrip strength, using Kincom isokinetic dynamometry (Isokinetic International, Chattanooga, TN, USA) [27] and Vernier dynamometry (Vernier software and Technology, Beaverton, OR, USA) respectively [28].

\subsection{Stable isotope infusion by IV pulse or continuous infusion}

In the early morning after an overnight fast, a peripheral line was placed in a vein of the lower arm for stable tracer infusion and in a superficial dorsal vein of the contralateral hand for blood sampling. The hand was placed in a thermostatically controlled hot box (internal temperature: $50{ }^{\circ} \mathrm{C}$ ), a technique to mimic direct arterial sampling [29]. Two methods of stable amino acid tracers were applied to investigate protein and amino acid kinetics on an individual level: first, a pulse method by analysing the decay curves of the tracer enrichments in plasma using (non)-compartmental modelling. This enables measuring the WbRa of amino acids with different pool sizes. The second method is a primed-constant infusion of stable tracers of amino acids with careful priming to obtain tracer steady state of PHE and TYR and measure whole body protein synthesis and breakdown [24].

For the pulse method, two syringes of a cocktail of stable amino acids $(15-30 \mathrm{~mL}$ ) tracers used to characterize muscle metabolism (Cambridge Isotope Laboratories, Cambridge, UK 140 (Wolburn, MA, USA)) [25] were administered intravenously after a venous blood sample was collected to measure baseline tracer enrichments (Table 1) [25].

We report the isotope labels and concentrations of the amino acids tau-methylhistidine (tau-MetHis), glycine (Gly), taurine (Tau) 
Table 1

Composition of the infused stable isotopes.

\begin{tabular}{|c|c|c|c|}
\hline Time & IV administration & Stable isotopes & Dose per $\mathrm{kg}$ body weight $(\mu \mathrm{mol} / \mathrm{kg} \mathrm{ffm})$ \\
\hline \multirow[t]{5}{*}{ Baseline } & Pulse & L-tau-Methylhistidine- $\left[{ }^{2} \mathrm{H}_{3}\right]$ & 0.061 \\
\hline & & L-Leucine- $\left[{ }^{2} \mathrm{H}_{3}\right]$ & 1.56 \\
\hline & & Glycine- $\left[{ }^{2} \mathrm{H}_{2}\right]$ & 9.37 \\
\hline & & L-Glutamine- $\left[5-{ }^{15} \mathrm{~N}\right]$ & 6.25 \\
\hline & & L-Taurine $\left[1,2-{ }^{13} \mathrm{C}_{2}\right]$ & 0.729 \\
\hline \multirow[t]{3}{*}{$+2 \mathrm{~h}$} & Primed-constant infusion & L-Phenylalanine-[ring- ${ }^{2} \mathrm{H}_{5}$ ] & Prime: $75 \%$ of hourly infusion rate \\
\hline & & & Infusion: 0.167 \\
\hline & & L-Tyrosine- $\left[{ }^{13} \mathrm{C}_{9^{-}}{ }^{15} \mathrm{~N}\right]$ & $\begin{array}{l}\text { Prime: } 75 \% \text { of hourly infusion rate } \\
\text { Infusion: } 0.0053\end{array}$ \\
\hline
\end{tabular}

Table 2

General characteristics, body composition, muscle function, dietary intake and physical activity of healthy controls and patients with cancer at enrolment.

\begin{tabular}{|c|c|c|c|}
\hline Mean (SEM), except when stated otherwise & Healthy controls $(\mathrm{n}=16)$ & Cancer patients $(\mathrm{n}=16)$ & P-value Healthy vs. Cancer \\
\hline Gender $(\mathrm{m} / \mathrm{f})-\mathrm{n}$ & $9 / 7$ & $9 / 7$ & 1.00 \\
\hline Age (y) & $59.3(4.0)$ & $60.1(4.2)$ & 0.90 \\
\hline Weight (kg) & $77.6(3.1)$ & $73.0(3.9)$ & 0.36 \\
\hline $\operatorname{BMI}\left(\mathrm{kg} / \mathrm{m}^{2}\right)$ & $26.7(0.8)$ & $26.8(1.4)$ & 0.95 \\
\hline \multicolumn{4}{|l|}{ BMI category } \\
\hline $20-25 \mathrm{~kg} / \mathrm{m}^{2}$ & $5(31)$ & $8(50)$ & 0.47 \\
\hline$>25-30 \mathrm{~kg} / \mathrm{m}^{2}$ & $7(44)$ & $4(25)$ & \\
\hline$>30 \mathrm{~kg} / \mathrm{m}^{2}$ & $4(25)$ & $4(25)$ & \\
\hline \multicolumn{4}{|l|}{ Body composition } \\
\hline FFM (kg) & $53.0(2.6)$ & $48.6(2.6)$ & 0.23 \\
\hline FFM-index $\left(\mathrm{kg} / \mathrm{m}^{2}\right)$ & $18.1(0.6)$ & $17.7(0.6)$ & 0.56 \\
\hline FFM-index extremities $\left(\mathrm{kg} / \mathrm{m}^{2}\right)$ & $7.7(0.3)$ & $7.3(0.3)$ & 0.34 \\
\hline Appendicular Skeletal Muscle Index (ASMI) & $7.3(0.3)$ & $6.9(0.3)$ & 0.30 \\
\hline Sarcopenia $^{\mathrm{a}}(\mathrm{n}, \%)$ & $3(19)$ & $6(38)$ & 0.24 \\
\hline Android/gynoid ratio & $1.0(0.04)$ & $1.0(0.06)$ & 0.26 \\
\hline Abdominal obesity (n, \%) & $11(69)$ & $10(63)$ & 0.34 \\
\hline \multicolumn{4}{|l|}{ Muscle function } \\
\hline Maximal inspiratory pressure $\left(\mathrm{cm} \mathrm{H}_{2} \mathrm{O}\right)$ & $115.8(10.5)$ & $72.2(7.6)$ & 0.009 \\
\hline Maximal expiratory pressure $\left(\mathrm{cm} \mathrm{H}_{2} \mathrm{O}\right)$ & $124.2(9.8)$ & $90.2(10.2)$ & 0.09 \\
\hline Handgrip strength $(\mathrm{N})$ & $291.6(16.5)$ & $235.9(23.0)$ & 0.06 \\
\hline Handgrip strength (N/kg FFM extremities) & $13.1(0.6)$ & $11.6(0.7)$ & 0.11 \\
\hline Leg extension strength $(\mathrm{N})$ & $374.1(36.1)$ & $252.6(29.5)$ & 0.01 \\
\hline Leg extension strength (N/kg FFM extremities) & $16.1(1.0)$ & $12.2(1.0)$ & 0.01 \\
\hline Leg flexion strength $(\mathrm{N})$ & $188.3(17.9)$ & $158.3(16.2)$ & 0.22 \\
\hline Leg flexion strength (N/kg FFM extremities) & $8.4(0.7)$ & $7.8(0.5)$ & 0.48 \\
\hline \multicolumn{4}{|l|}{ Dietary intake and physical activity } \\
\hline Energy intake (kcal/d) & $1949(131)$ & $1724(214)$ & 0.38 \\
\hline Protein intake $(\mathrm{g} / \mathrm{kg} / \mathrm{d})$ & $1.07(0.05)$ & $1.06(0.17)$ & 0.93 \\
\hline Physical activity level (PASE-questionnaire) & $165.1(20.7)$ & $135.0(25.1)$ & 0.36 \\
\hline
\end{tabular}

ASMI, appendicular skeletal muscle index; BMI, body mass index; FFM, fat free mass, PASE Physical Activity Scale for the Elderly.

Bold values represents $\mathrm{P}<0.05$.

and glutamine (Gln), known to play a role in muscle metabolism (Table 1 ). In addition, $2 \mathrm{~h}$ after the pulse we started a primed constant and continuous infusion of the stable tracers of phenylalanine and tyrosine, lasting for $4 \mathrm{~h}$.

Arterialized-venous blood was sampled at multiple time points at $\mathrm{t}=2,5,10,15,20,30,40,50,60,90,120 \mathrm{~min}$ after pulse administration and 30, 60, 90 and 105 and 120 min after starting the continuous infusion.

Blood samples were taken for analysis of the tracer enrichments and concentrations of amino acids.

\subsection{Questionnaires}

On the day of the study, habitual dietary intake was assessed by 24-h dietary recall, a retrospective method that consists of recalling, describing and quantifying the intake of foods and beverages consumed in the past $24 \mathrm{~h}$. This information was used for coding and analysed for energy and protein intake. Habitual physical activity level was measured by the Physical Activity Scale for the Elderly questionnaire (PASE) [30]. This questionnaire, intended for use in an older adult population, has been validated to measure self-reported physical activity in lung cancer [31] and focuses on 3 types of activities: leisure time activities, household activities and work-related activities.

In patients with cancer, the Karnofsky Performance Score was used to assess functional status. The Karnofsky Performance Score describes functional status as a comprehensive 11-point scale correlating to percentage values ranging from 100\% (no evidence of disease, no symptoms) to $0 \%$ (death) [32,33]. Patients with cancer also completed the European Organization for Research and Treatment of Cancer (EORTC) Quality of Life Questionnaire C30 (EORTC-QLQ-C30) [34]. The EORTC-QLQ-C30 Quality of Life (QOL) score reflects how patients rate their overall health and quality of life. The EORTC-QLQ-C30 daily physical function score expresses the capacity to perform normal daily activities and varies from 0 to 100 , with a high score representing a high level of functioning.

\subsection{Biochemical analysis}

Arterialized-venous blood was put in Li-heparinized or EDTA tubes (Becton Dickinson Vacutainer system, Franklin Lakes, New Jersey, USA), immediately put on ice to minimize enzymatic 
reactions, and centrifuged $\left(4^{\circ} \mathrm{C}, 3120 \times \mathrm{g}\right.$ for $5 \mathrm{~min}$ ) to obtain plasma. A part of the plasma was aliquoted into tubes with $0.1 \mathrm{vol}$ of $33 \%(\mathrm{w} / \mathrm{w})$ trichloroacetic acid or a residue after evaporation of 0.17 vol of 33\% (w/w) 5-sulfosalicylic dihydrate, and then vortexed for denaturation of proteins. Samples were instantly frozen and stored at $-80{ }^{\circ} \mathrm{C}$ until further analysis. Tracer enrichments [tracer:tracee ratio (TTR)] and plasma amino acid concentrations were analysed by LC-MS/MS by isotope dilution as previously reported [14,24]. All samples were analysed batchwise.

\subsection{Calculations of metabolic parameters}

Sum of amino acids (sum AA) represents the sum of the concentration of all measured amino acids. BCAA is the sum of valine (Val), leucine (Leu) and isoleucine (Ile). Sum of essential (sum EAA) amino acids represents the sum of histidine (His), isoleucine (Ile), Leu, lysine (Lys), Phe, methionine (Met), threonine (Thr), tryptophan (Trp) and Val.

Whole body protein synthesis (WBPS), protein breakdown (WBPB) and net protein breakdown (WBnetPB) were calculated from the isotope enrichment values of L-Phe-[ring- $\left.{ }^{2} \mathrm{H}_{5}\right]$ and L-Tyr[ring- ${ }^{2} \mathrm{H}_{2}$ ] [35]. Metabolic data were obtained at isotopic steady state and rates were calculated using the standard steady state isotope dilution equation [36]. TTR of Phe and Tyr reached an isotopic steady state within $2 \mathrm{~h}$ of infusion in both groups.

Whole body production (WBP) rates for all other tracers given with the pulse were measured by non-compartmental analysis [24]. GraphPad Prism (version 7.0d) was used for noncompartmental analysis.

The change in TTR over time was fitted [36] and the area under the curve (AUC) was obtained as previously described [24]. We calculated the conversion of an amino acid by using the Ra of the product amino acid and the ratio between the TTR at plateau or AUC of the TTR from pulse of the product/substrate [24,37,38]. Clearance rate of an amino acid was calculated as Ra/plasma concentration of that amino acid [36].

\subsection{Statistical analysis}

Results are expressed as means \pm standard errors (SE). Population characteristics and baseline measurements were compared with the use of the either the unpaired Student's t-test (if data were distributed normally) or the Mann-Whitney test. Alternatively, categorical values were compared with the use of the Pearson Chi-Square test. Bivariate Pearson's correlation analysis was used to measure the linear correlation between muscle function, mass and each metabolic variable. The statistical package within Graphpad Prism (Version 7.0d) and SPSS (version 25) was used for data analysis. The level of statistical significance was set at $\mathrm{P}<0.05$.

\section{Results}

Sixteen patients with solid tumours undergoing chemotherapy and 16 age- and sex matched healthy controls were studied (Tables 2 and 3). The average age was 59.3 years in healthy subjects and 60.1 years in patients with cancer $(P=0.90)$. In both groups, $44 \%$ of the subjects were female. The cancer group formed a heterogeneous group that varied in tumour type, treatment regimen and Karnofsky performance score (Table 3 ). One patient with cancer had stage IIb, 8 had stage III and 7 patients had stage IV disease. The median time since last chemotherapy was 7 days (range 0-16 days). Five out of 16 patients received chemotherapy and concurrent radiotherapy. Fifty per cent of the patients with cancer reported weight loss in the previous month, with an average \% of weight loss of $2.5 \pm 2.9 \%$. Pre-cachexia was present in 1 patient when using criteria suggested by Fearon et al. ( $<5 \%$ weight loss, EORTC QLQ-c30 appetite loss > 21.1 and albumin $<$ reference value) [3]. Two patients were classified as having cachexia based on Fearon's criteria ( $\geq 5 \%$ weight loss and $\mathrm{BMI}<20$ or sarcopenia, based on: ASMI $<7.23 \mathrm{~kg} / \mathrm{m}^{2}$ for men; $<5.67 \mathrm{~kg} / \mathrm{m}^{2}$ for women).

\subsection{Body composition and muscle function}

Secondary sarcopenia (defined as ASMI $<7.23 \mathrm{~kg} / \mathrm{m}^{2}$ for men; $<5.67 \mathrm{~kg} / \mathrm{m}^{2}$ for women) [39] was present in $38 \%$ of the patients with cancer, while 10 (63\%) were abdominally obese (defined as android/gynoid \% FM $>1.0$ for men, $>0.8$ for women) [40], compared to $19 \%$ of healthy subjects with sarcopenia and 11 (69\%) with abdominal obesity. BMI, whole body FFMI, ASMI, and MEP were not different between the groups, but MIP and leg extension strength were lower in patients with cancer $(P<0.05)$. Patients with cancer tended to have lower handgrip strength than healthy controls $(P=0.06)$. Energy and protein intake and reported physical activity level were not different between healthy subjects and patients with cancer (Table 2).

\subsection{Protein metabolism}

Post absorptive plasma concentrations of the amino acids Phe, Tyr, and tau-MetHis were comparable between patients with cancer and healthy subjects (Table 4). In contrast, the WBP and clearance of tau-MetHis (Table 4) were significantly higher in patients with cancer than in healthy controls (0.29 vs.0.20 $\mu \mathrm{mol} / \mathrm{kg} \mathrm{FFM} / \mathrm{h}$ (+45\%), $\mathrm{p}=0.03$ and 0.07 vs. $0.04 \mathrm{~L} / \mathrm{min}(+75 \%), \mathrm{p}<0.001$, respectively). This indicates a higher whole body myofibrillar protein breakdown in cancer patients than in healthy controls. Conversion of phenylalanine to tyrosine (post absorptive WBnetPB) was not different between patients with cancer and healthy subjects.

Plasma Leu, BCAA, sum EAA and sum AA concentrations were comparable between patients with cancer and healthy controls (Table 4). However, WBP and clearance of leucine were substantially higher in patients with cancer than in healthy controls (respectively 114.3 vs. $66.3 \mu \mathrm{mol} / \mathrm{kg} \mathrm{FFM} / \mathrm{h}, \mathrm{P}<0.001$, and 1.42 vs. $0.78 \mathrm{~L} / \mathrm{min}, \mathrm{p}<0.001$ ) (Table 4).

\subsection{Metabolism of the remaining amino acids known to affect muscle contractility (Tau, Gly, Gln)}

The cancer group was characterized by a lower plasma concentration value of Tau ( 29.9 vs. $36.3 \mu \mathrm{M}, \mathrm{P}<0.05)$, but had comparable values to healthy controls for plasma Gly (Table 4). WBP and clearance of Tau were higher in patients with cancer (respectively 40.6 vs. $25.9 \mu \mathrm{mol} / \mathrm{kgFFM} / \mathrm{h}, \mathrm{P}<0.001$ and $1.41 \mathrm{vs.} 0.75 \mathrm{~L} / \mathrm{min}$, $\mathrm{P}<0.001)$, as well as the clearance of Gly $(1.26 \mathrm{vs} .0 .86 \mathrm{~L} / \mathrm{min}$, $\mathrm{P}=0.01$ ) (Table 4). Plasma Gln was not different between patients with cancer and healthy controls, but WBP and clearance were higher (respectively 491.4 vs. $325.2, \mathrm{P}=0.008$ and $1.12 \mu \mathrm{mol} / \mathrm{kg}$ FFM/h vs. $0.70 \mathrm{~L} / \mathrm{min}, \mathrm{P}=0.001$ ) (Table 4 ).

\subsection{Relationships between muscle mass, function and amino acid metabolism in patients with cancer}

\subsubsection{Appendicular skeletal muscle mass}

In patients with cancer, reduced ASMI was strongly associated with muscle weakness as reflected by lower values for handgrip strength ( $\mathrm{r}$ : 0.66, $\mathrm{P}=0.005)$, maximum leg extension ( $\mathrm{r}$ : 0.65, $\mathrm{P}=0.007$ ), and respiratory muscle strength (MEP, $\mathrm{r}: 0.51, \mathrm{P}=0.04$ ). ASMI was not significantly correlated to Karnofsky performance score or EORTC-QLQ-C30 Physical Function and Quality of Life. 
Table 3

Characterization of patients with cancer.

\begin{tabular}{|c|c|c|}
\hline Tumour type & $\mathrm{n}(\%)$ & \\
\hline Esophageal & & $2(13)$ \\
\hline Gastric/laryngeal & & $1(6)$ \\
\hline Colorectal & & $6(38)$ \\
\hline Lung & & $3(19)$ \\
\hline Ovarian & & $3(19)$ \\
\hline Histology & $\mathrm{n}(\%)$ & \\
\hline Small cell & & $1(6)$ \\
\hline Poorly differentiated & & $1(6)$ \\
\hline Unknown & & $2(13)$ \\
\hline Stage & $\mathrm{n}(\%)$ & \\
\hline IIb & & $1(6)$ \\
\hline Albumin $(\mathrm{g} / \mathrm{dL})[34-47]$ & & $38(1.4)$ \\
\hline WCC $\left(\times 10^{9} / \mathrm{L}\right)[4.8-10.8]$ & & $5.4(0.6)$ \\
\hline Physical performance & $\mathrm{n}(\%)$ & \\
\hline \multicolumn{3}{|l|}{ Karnofsky performance Score } \\
\hline 60 & & $1(6)$ \\
\hline 70 & & $2(13)$ \\
\hline 80 & & $5(31)$ \\
\hline 90 & & $3(19)$ \\
\hline 100 & & $1(12)$ \\
\hline Unknown & & $4(25)$ \\
\hline Physical function (EORTC-QLQ-C30) & mean (SEM) & $83.3(16.7)$ \\
\hline Appetite loss (EORTC-QLQ-C30) & & $29.2(9.6)$ \\
\hline + Bevacizumab & & $3(19)$ \\
\hline + Irinotecan & & $1(6)$ \\
\hline Concurrent radiotherapy & $\mathrm{n}(\%)$ & $5(31)$ \\
\hline \multicolumn{3}{|l|}{ Unintentional weight loss } \\
\hline$\%$ weight loss in previous month & mean (SEM) & $2.5(0.8)$ \\
\hline$\geq 5 \%$ weight loss in previous month & $\mathrm{n}(\%)$ & $6(37.5)$ \\
\hline Number of hospitalisations in last year & $\mathrm{n}(\%)$ & \\
\hline 0 & & $5(31)$ \\
\hline 1 & & $8(50)$ \\
\hline 2 & & $2(13)$ \\
\hline 3 & & - \\
\hline 4 & & - \\
\hline 5 & & $1(6)$ \\
\hline
\end{tabular}

Relationships were found between a low ASMI and amino acid disturbances as reflected by higher values for the whole body production of $\mathrm{Gln}(\mathrm{r}:-0.63, \mathrm{P}=0.02)$ and Tau $(\mathrm{r}:-0.56, \mathrm{P}=0.04)$, higher clearance rates of $\mathrm{Gln}(\mathrm{r}$ : $-0.67, \mathrm{P}=0.01)$, lower values for plasma Phe concentration ( $\mathrm{r}: 0.61, \mathrm{P}=0.02$ ).

\subsubsection{Muscle strength}

Relationships were found between low handgrip strength and metabolic disturbances in patients with cancer as reflected by reduced plasma levels of Phe ( $\mathrm{r}: 0.73, \mathrm{P}=0.003$; Fig. 1$)$ and Tyr ( $\mathrm{r}$ : $0.63, P=0.02)$ and elevated rates of clearance of Phe $(r:-0.66$, $\mathrm{P}=0.01)$, Tyr ( $\mathrm{r}:-0.574, \mathrm{P}=0.03)$ and $\mathrm{Gln}(\mathrm{r}:-0.65, \mathrm{P}=0.02)$. Muscle strength was not significantly correlated to Karnofsky performance score or EORTC-QLQ-C30 Physical Function and Quality of Life.

Leg muscle weakness was associated with lower plasma concentrations of Phe (r: 0.60, $\mathrm{P}=0.02)$ and Tyr $(\mathrm{r}: 0.61,=0.01)$.
3.4.3. EORTC-QLQ-C30 physical function and quality of life

Lower reported daily physical function scores in cancer were associated with lower plasma concentrations of Leu ( $\mathrm{r}: 0.60$, $\mathrm{P}=0.02$ ), Tau ( $\mathrm{r}: 0.59, \mathrm{P}=0.03$ ), EAA ( $\mathrm{r}: 0.55, \mathrm{P}=0.041$ ), Sum AA ( $\mathrm{r}$ : $0.55, \mathrm{P}=0.04)$ and with higher clearance rates of Leu ( $\mathrm{r}:-0.62$, $\mathrm{p}=0.02)$, Gly $(\mathrm{r}=-0.59, \mathrm{P}=0.04)$ and Tau $(\mathrm{r}:-0.77, \mathrm{P}=0.002)$ (Fig. 2).

Lower self-reported quality of life scores were associated with higher rates of Tau clearance ( $\mathrm{r}$ : $-0.57, \mathrm{P}=0.04$ ).

\section{Discussion}

In the present study, we examined the (protein and amino acid) metabolic characteristics of a well-described heterogeneous group of non-cachectic patients with advanced solid tumours undergoing chemotherapy. We observed no significant weight loss, muscle wasting or reduced dietary intake, but an evident 
Table 4

Post-absorptive concentrations in plasma and non-compartmental rate of appearance and clearance of amino acids in healthy controls and patients with cancer.

\begin{tabular}{|c|c|c|c|}
\hline Mean (SEM) & Healthy controls $(n=16)$ & Cancer patients $(\mathrm{n}=16)$ & P-value Healthy vs. Cancer \\
\hline \multicolumn{4}{|l|}{ Plasma concentration } \\
\hline Phenylalanine ( $\mu \mathrm{mol} / \mathrm{L})$ & $42.2(2.3)$ & $42.5(2.4)$ & 0.93 \\
\hline Tyrosine $(\mu \mathrm{mol} / \mathrm{L})$ & $43.8(2.7)$ & $45.5(3.0)$ & 0.68 \\
\hline Tau-Methylhistidine $(\mu \mathrm{mol} / \mathrm{L})$ & $5.25(0.33)$ & $4.73(0.49)$ & 0.39 \\
\hline Glycine $(\mu \mathrm{mol} / \mathrm{L})$ & $190.0(12.1)$ & $218.8(31.3)$ & 0.40 \\
\hline Leucine $(\mu \mathrm{mol} / \mathrm{L})$ & $97.7(5.3)$ & $86.9(7.5)$ & 0.25 \\
\hline Glutamine & $453.0(18.7)$ & $452.9(21.3)$ & 1.00 \\
\hline Taurine & $36.3(1.6)$ & $29.9(1.8)$ & 0.02 \\
\hline Sum BCAAs $(\mu \mathrm{mol} / \mathrm{L})$ & $334.6(16.6)$ & $307.0(25.6)$ & 0.37 \\
\hline Sum EAA $(\mu \mathrm{mol} / \mathrm{L})$ & $734.4(30.8)$ & $688.2(42.8)$ & 0.38 \\
\hline Sum AA $(\mu \mathrm{mol} / \mathrm{L})$ & $2052.3(64.0)$ & $2037.1(98.0)$ & 0.90 \\
\hline \multicolumn{4}{|l|}{ Rate of appearance } \\
\hline Phenylalanine $(\mu \mathrm{mol} / \mathrm{kg} \mathrm{ffm} / \mathrm{h})$ & $88.6(3.9)$ & $91.0(2.7)$ & 0.62 \\
\hline Tyrosine $(\mu \mathrm{mol} / \mathrm{kg} \mathrm{ffm} / \mathrm{h})$ & $58.3(4.4)$ & $61.9(1.7)$ & 0.45 \\
\hline Conversion of phenylalanine to tyrosine ( $\mu \mathrm{mol} / \mathrm{kg} \mathrm{ffm} / \mathrm{h}$ ) & $6.8(0.6)$ & $5.8(0.3)$ & 0.17 \\
\hline Tau-Methylhistidine ( $\mu \mathrm{mol} / \mathrm{kg} \mathrm{ffm} / \mathrm{h})$ & $0.20(0.02)$ & $0.29(0.03)$ & 0.03 \\
\hline Glycine $(\mu \mathrm{mol} / \mathrm{kg} \mathrm{ffm} / \mathrm{h})$ & $152.9(18.5)$ & $215.9(25.4)$ & 0.05 \\
\hline Leucine $(\mu \mathrm{mol} / \mathrm{kg} \mathrm{ffm} / \mathrm{h})$ & $66.3(5.7)$ & $114.3(6.7)$ & $<0.001$ \\
\hline Glutamine $(\mu \mathrm{mol} / \mathrm{kg} \mathrm{ffm} / \mathrm{h})$ & $325.2(51.5)$ & $491.4(32.0)$ & 0.008 \\
\hline Taurine $(\mu \mathrm{mol} / \mathrm{kg} \mathrm{ffm} / \mathrm{h})$ & $25.9(2.6)$ & $40.1(2.2)$ & $<0.001$ \\
\hline \multicolumn{4}{|l|}{ Clearance } \\
\hline Phenylalanine (L/min) & $2.18(0.12)$ & $2.27(0.20)$ & 0.68 \\
\hline Tyrosine (L/min) & $1.40(0.07)$ & $1.43(0.11)$ & 0.79 \\
\hline Tau-Methylhistidine (L/min) & $0.04(0.00)$ & $0.07(0.01)$ & $<0.001$ \\
\hline Glycine (L/min) & $0.88(0.09)$ & $1.26(0.11)$ & 0.01 \\
\hline Leucine (L/min) & $0.78(0.08)$ & $1.42(0.23)$ & $<0.001$ \\
\hline Glutamine (L/min) & $0.70(0.09)$ & $1.13(0.08)$ & 0.001 \\
\hline Taurine $(\mathrm{L} / \mathrm{min})$ & $0.75(0.07)$ & $1.39(0.08)$ & $<0.001$ \\
\hline
\end{tabular}

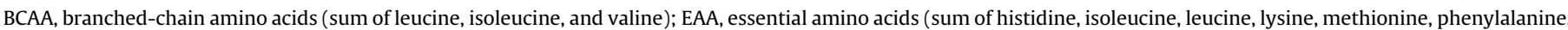
threonine, tryptophan and valine); AA, amino acids (sum of all amino acids).

Bold values represents $\mathrm{P}<0.05$.

limb muscle weakness and a consistently increased amino acid turnover and myofibrillar protein breakdown in patients with cancer as compared to healthy controls. In addition, we showed that disturbances in protein metabolism in cancer patients were associated with appendicular muscle loss, muscle weakness, and low daily physical function and quality of life scores, showing the overall impact of metabolic changes on physical health and wellbeing.

\subsection{Protein metabolism in relation to muscle mass and function}

We found an increased contractile (myofibrillar) protein breakdown rate compared to age matched control subjects, while

\section{Muscle strength}

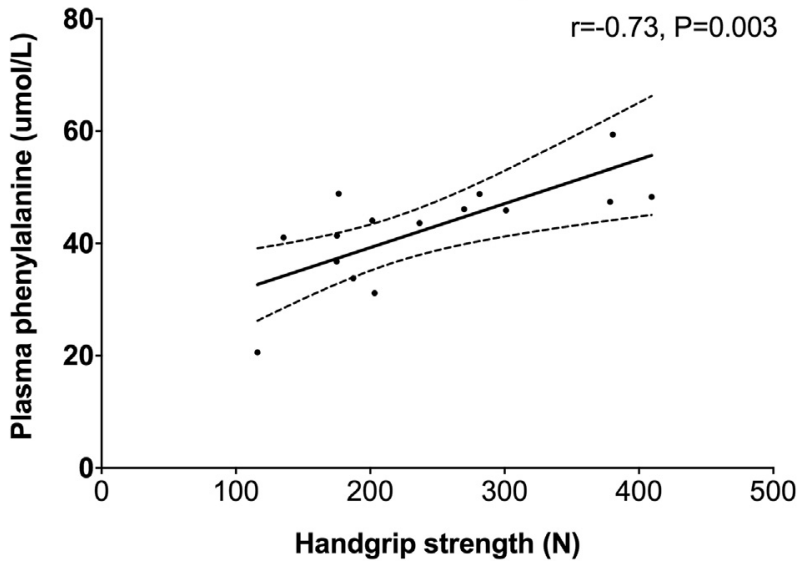

Fig. 1. Correlation between handgrip strength and plasma phenylalanine in patients with cancer. net whole body protein catabolism was unchanged. Most of the total body tau-MetHis pool is present in skeletal muscle, and solely in myofibrillar protein $[41,42]$. As proteolysis of myofibrils releases tau-MetHis that cannot be reused, the WBP of tau-MetHis in plasma was used to estimate myofibrillar protein breakdown. Our group recently showed an increased production of tau-MetHis in healthy older adults compared to younger adults using the same tracer pulse approach [24], although older adults have comparable muscle mass, but reduced leg strength. In the present study, patients with cancer also exhibit limb muscle weakness without muscle mass loss. This suggests that tau-MetHis WBP relates to the reduction in strength. The reduction in muscle strength is also present in patients with non-small cell lung cancer with ECOG

\section{EORTC Physical functioning}

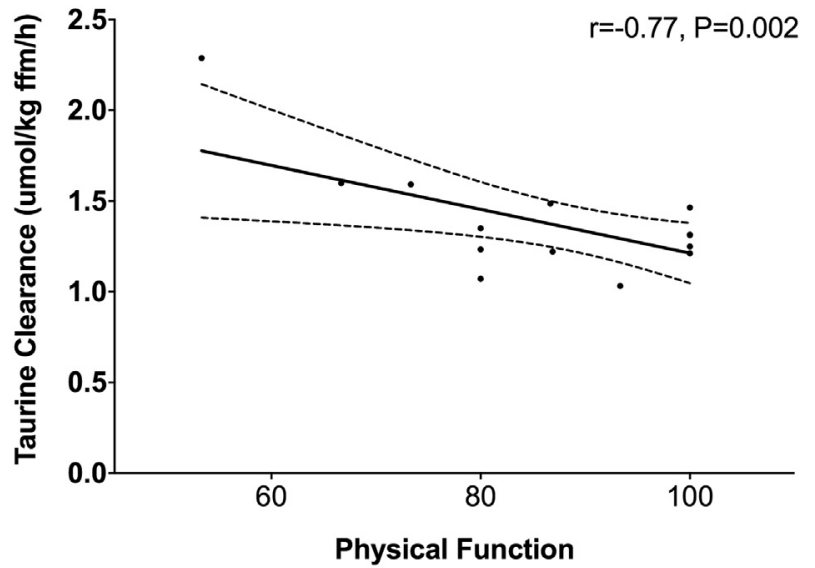

Fig. 2. Correlation between physical function and taurine clearance in patients with cancer. 
performance status 0 or 1 (able to carry out normal, or fairly normal daily activities) and who had less than $10 \%$ weight loss [43]. A metaanalysis of studies in breast cancer also showed a lower upper and lower extremity strength in women who were receiving breast cancer treatment [44]. Cancer patients are more characterized by reductions in muscle strength that relate to the WBP of tau-MetHis. Another explanation of muscle weakness related to metabolic abnormalities in cancer is muscle fat infiltration, indicated by muscle attenuation on CT-images [4].

To measure the production of tau-MetHis by stable tracer methodology is more accurate to determine myofibrillar protein breakdown than using plasma concentrations or urine excretion [41]. Older studies have found a higher excretion of tau-MetHis via the urine in catabolic conditions [45-47]. Using stable tracers, we found in tumour-bearing mice a higher production of tau-MetHis compared to controls [48]. Apart from the production of tauMetHis, the production of glutamine has scarcely been investigated in humans with cancer, due to difficulties to measure glutamine WBP with a primed-continuous protocol [49]. Our pulse methodology allows quantifying the production (rate of appearance) and clearance of glutamine. Our results indicated that production and clearance, rather than plasma concentrations, of glutamine were important markers for metabolic changes in cancer, and that the clearance of glutamine negatively correlated to muscle mass and muscle strength. There were no correlations between the glutamine and tau-MetHis metabolism. These findings in patients with cancer have not been published before.

To explore the clinical relevance of abnormal metabolism of several other amino acids, we investigated relationships between metabolic markers and muscle strength, daily physical function and QOL. We found that lower strength, daily physical function and QOL scores were associated with higher clearance rates or lower plasma values of phenylalanine, tyrosine, taurine, leucine or glutamine, indicating a higher disposal of these amino acids.

Lower levels of daily physical function and QOL were related to glycine and taurine clearance rates, indicating disposal of these amino acids relates to patient-reported outcomes. Glycine is a precursor for metabolites such as creatine and glutathione, and is involved in muscle synthesis [50]. It has been shown in patients with cancer that supplemental glycine attenuates muscle wasting during dieting or fasting, and reduces muscle wasting. Taurine is abundant in muscle cells and plays a role in the defence against free radical-mediated damage after exercise [51], and has a regulatory effect on ion channels, calcium homeostasis, oxidative stress and control of membrane excitability [52].

\subsection{Weight loss, sarcopenia and obesity}

We found no weight loss in contrast to reported in the literature, despite the advanced stages of our cancer group (mainly stage III and IV). In a study by Hebuterne and co-workers, weight loss $>10 \%$ or underweight were present in $39 \%$ of patients with cancer and depending on tumour sites, this prevalence varied from $1.9 \%$ in prostate cancer to $60.2 \%$ in pancreatic cancer [53]. Others document malnutrition in patients starting radiotherapy for colorectal, head and neck, breast, lung or stomach cancer, malnutrition in $31 \%$ and it increased to $43 \%$ at the end of radiotherapy [54]. Even at the first oncology visit, a recently published Italian study observed $9 \%$ of malnutrition and $43 \%$ at risk of malnutrition [55]. In the current study, only $6 \%$ of patients undergoing chemotherapy experienced more than 5\% weight loss in 1 month. However, secondary sarcopenia was present in $37.5 \%$.

What are the reasons for this difference in the prevalence of weight loss? We found that our patients with cancer did not experience a high level of anorexia, as they were able to maintain sufficient dietary protein and calorie intake. However, we found that the current patient group had a low level of inflammation, as most of them were not anaemic and had normal levels of the negative acute-phase-protein albumin. As we detected several metabolic disturbances with our tracer methodologies, we hypothesize that many of our patients were pre-cachectic [3], characterized by disturbed metabolism that did not yet lead to any measurable muscle loss but with significant muscle weakness. This suggests that treatment that aims to reduce muscle weakness need to be initiated in the pre-cachexia phase aiming at normalizing the observed metabolic disturbances.

Obesity is an upcoming phenomenon in our society and as a result, rates of obesity in the cancer population show the same trend in the increased prevalence of obesity as the general population [20]. Of patients with cancer in the current study, $50 \%$ were overweight or obese, which is comparable with the literature [56]. None were reporting any fluid retention that could cause overestimation of BMI and presence of obesity. As obesity increases the risk of muscle weakness, loss and treatment toxicity [57], these pre-cachectic patients require nutrition assessment and appropriate nutrition support, just as much as patients who have cachexia or underweight.

Our data showing elevated levels of protein turnover, myofibrillar protein breakdown and muscle wasting correspond with other metabolic studies in small groups of cancer patients $[19,48,58]$ and therefore we think that our study provides useful information about protein metabolism in patients undergoing chemotherapy. We showed that even in patients who would not be classified as pre-cachectic or cachectic, the body responds to the disease and the treatment, resulting in a significantly higher protein turnover and myofibrillar protein breakdown and many deteriorations in the production and clearance rate of amino acids, which were related to muscle function, physical function and quality of life. These novel findings can be used for clinicians to be aware of metabolic changes that do not yet translate into clinical impairments. The higher protein turnover and alterations in amino acid metabolism in non-cachectic patients with cancer indicates a probable higher demand for dietary protein. An increased protein intake has been shown to promote muscle protein anabolism [59] and is recommended by the ESPEN guidelines for patients with cancer [60]. We know that many patients potentially can have a problem reaching adequate and optimal protein intakes. Future research should look at metabolic and functional changes in large and heterogeneous groups of cancer, and ideally investigate effects of different chemotherapy regimens on protein metabolism.

\subsection{Limitations}

A limitation of this study is that the group is small and heterogeneous. The group might not be representative for all patients with cancer undergoing chemotherapy, as we enrolled 6 different types of cancer with small numbers representing each cancer type. Our data probably represent metabolic changes that occur in many patients with cancer undergoing chemotherapy. Some preclinical studies indicate effects of certain chemotherapy drugs on muscle metabolism [8,9], like handgrip strength [6,7] and quadriceps strength [6]. In the current study, we are measuring heterogeneous patients with cancer undergoing different types of chemotherapy and cannot isolate the effect of chemotherapy. Also, as patients with progressive disease who were unwell were not able to participate in this full day metabolic study, which could have caused selection bias and could explain the relatively low amount of muscle wasting and muscle weakness, and relatively high quality of life in this study.

In conclusion, this study shows that pre-cachectic patients with advanced cancer undergoing chemotherapy with reduced muscle 
strength and unchanged muscle mass and normal reported physical activity have already an increased amino acid turnover and myofibrillar protein breakdown that relates to their reduced muscle strength and physical function.

\section{Funding sources}

This study was supported by a European Society for Clinical Nutrition and Metabolism (ESPEN) Research Fellowship in 2013.

\section{Statement of authorship}

BM collected data, analysed data and wrote the manuscript.

ND designed the study, coordinated the study and wrote the manuscript.

RR assisted with recruiting subjects and assisted with writing the manuscript.

ME designed the study, coordinated the study and wrote the manuscript.

\section{Conflict of interest}

The authors declare no conflict of interest.

\section{Acknowledgements}

This study was supported by a European Society for Clinical Nutrition and Metabolism (ESPEN) Research Fellowship in 2013. We would like to thank Scott \& White Hematology/Oncology Clinic, St Joseph Regional Cancer Center, Aggieland Cancer Treatment Center and MD Anderson Cancer Center for their help with recruitment.

\section{Appendix A. Supplementary data}

Supplementary data to this article can be found online at https://doi.org/10.1016/j.clnu.2018.10.022.

\section{References}

[1] Ryan AM, Power DG, Daly L, Cushen SJ, Bhuachalla E E Ní, Prado CM. Cancerassociated malnutrition, cachexia and sarcopenia: the skeleton in the hospital closet 40 years later. Proc Nutr Soc [Internet] 2016 May 20;75(2):199-211 [cited 2017 Nov 3]. Available from: http://www.journals.cambridge.org/ abstract S002966511500419X.

[2] Hung Y-C, Bauer J, Horsley P, Waterhouse M, Bashford J, Isenring E. Changes in nutritional status, body composition, quality of life, and physical activity levels of cancer patients undergoing autologous peripheral blood stem cell transplantation. Support Care Cancer [Internet] 2013;21(6):1579-86. Available from: http://link.springer.com/10.1007/s00520-012-1698-y.

[3] Fearon K, Strasser F, Anker SD, Bosaeus I, Bruera E, Fainsinger RL, et al. Definition and classification of cancer cachexia: an international consensus. Lancet Oncol 2011;12(5):489-95.

[4] Martin L, Birdsell L, Macdonald N, Reiman T, Clandinin MT, McCargar LJ, et al. Cancer cachexia in the age of obesity: skeletal muscle depletion is a powerful prognostic factor, independent of body mass index. J Clin Oncol [Internet] 2013 Apr 20;31(12):1539-47 [cited 2017 Dec 22]. Available from: http:// ascopubs.org/doi/10.1200/JCO.2012.45.2722.

[5] Norman K, Stobäus N, Smoliner C, Zocher D, Scheufele R, Valentini L, et al. Determinants of hand grip strength, knee extension strength and functional status in cancer patients. Clin Nutr [Internet] 2010 Oct;29(5):586-91 [cited 2017 Nov 26]. Available from: http://www.ncbi.nlm.nih.gov/pubmed/ 20299136.

[6] Vermaete N, Wolter P, Verhoef G, Gosselink R. Physical activity and physical fitness in lymphoma patients before, during, and after chemotherapy: a prospective longitudinal study. Ann Hematol 2014;93(3):411-24.

[7] Teodozio CGC, Chaves GV, Arcuri IP, Frajacomo FT. Does grip strength decrease in the very early stages of hematological treatment? Support Care Cancer $2017 ; 1-3$.

[8] Van Norren K, Van Helvoort A, Argilés JM, Van Tuijl S, Arts K, Gorselink M, et al. Direct effects of doxorubicin on skeletal muscle contribute to fatigue. Br J Cancer 2009;100(2):311-4.
[9] Gilliam LAA, St Clair DK. Chemotherapy-induced weakness and fatigue in skeletal muscle: the role of oxidative stress. Antioxid Redox Signal [Internet] 2011 Nov 1;15(9):2543-63 [cited 2017 Nov 3]. Available from: http://www. liebertonline.com/doi/abs/10.1089/ars.2011.3965.

[10] Petruzzelli M, Wagner EF. Mechanisms of metabolic dysfunction in cancerassociated cachexia. Genes Dev [Internet] 2016 Mar 1;30(5):489-501 [cited 2017 May 22]. Available from: http://genesdev.cshlp.org/lookup/doi/10.1101/ gad.276733.115.

[11] Durham WJ, Dillon EL, Sheffield-Moore M. Inflammatory burden and amino acid metabolism in cancer cachexia. Curr Opin Clin Nutr Metab Care 2009:72-7.

[12] Hill A, Kiss N, Hodgson B, Crowe TC, Walsh AD. Associations between nutritional status, weight loss, radiotherapy treatment toxicity and treatment outcomes in gastrointestinal cancer patients. Clin Nutr [Internet] 2011 Feb;30(1):92-8 [cited 2017 Nov 10]. Available from: http://linkinghub. elsevier.com/retrieve/pii/S0261561410001469.

[13] Sánchez-Lara K, Ugalde-Morales E, Motola-Kuba D, Green D. Gastrointestinal symptoms and weight loss in cancer patients receiving chemotherapy. $\mathrm{Br}$ Nutr [Internet] 2013;109(5):894-7. Available from: http://www.ncbi.nlm.nih. gov/pubmed/22691288.

[14] Engelen MP, Safar AM, Bartter T, Koeman FDN. Reduced arginine availability and nitric oxide synthesis in cancer is related to impaired endogenous arginine synthesis. Clin Sci 2016;130(14):1185-95.

15] van Dijk DP, van de Poll MC, Moses AG, Preston T, Olde Damink SW, Rensen SS, et al. Effects of oral meal feeding on whole body protein breakdown and protein synthesis in cachectic pancreatic cancer patients. J Cachexia Sarcopenia Muscle [Internet] 2015 Sep;6(3):212-21 [cited 2016 Jul 12]. Available from: http://www.ncbi.nlm.nih.gov/pubmed/26401467.

[16] Lai H-S, Lee J-C, Lee P-H, Wang S-T, Chen W-J. Plasma free amino acid profile in cancer patients. Semin Cancer Biol [Internet] 2005 Aug;15(4):267-76 [cited 2017 Nov 3]. Available from: http://linkinghub.elsevier.com/retrieve/pii/ S1044579X05000209.

[17] Miyagi E, Maruyama Y, Mogami T, Numazaki R, Ikeda A, Yamamoto H, et al Comparison of plasma amino acid profile-based index and CA125 in the diagnosis of epithelial ovarian cancers and borderline malignant tumors. Int Clin Oncol [Internet] 2017 Feb 13;22(1):118-25 [cited 2017 Nov 28]. Available from: http://www.ncbi.nlm.nih.gov/pubmed/27623814.

[18] Williams JP, Phillips BE, Smith K, Atherton PJ, Rankin D, Selby AL, et al. Effect of tumor burden and subsequent surgical resection on skeletal muscle mass and protein turnover in colorectal cancer patients. Am J Clin Nutr [Internet] 2012;96(5):1064-70. Available from: http://www.ncbi.nlm.nih.gov/pubmed/ 23034966.

[19] MacDonald AJ, Johns N, Stephens N, Greig C, Ross JA, Small AC, et al. Habitual myofibrillar protein synthesis is normal in patients with upper GI cancer cachexia. Clin Cancer Res [Internet] 2015;21(7):1734-40. Available from: http://www.ncbi.nlm.nih.gov/pubmed/25370466.

[20] Engelen MPKJ, van der Meij BS, Deutz NEP. Protein anabolic resistance in cancer: does it really exist? Curr Opin Clin Nutr Metab Care [Internet] 2016;19(1):39-47. Available from: http://www.scopus.com/inward/record url?eid=2-s2.0-84951905019\&partnerID=tZOtx3y1.

[21] Dillon EL, Volpi E, Wolfe RR, Sinha S, Sanford AP, Arrastia CD, et al. Amino acid metabolism and inflammatory burden in ovarian cancer patients undergoing intense oncological therapy. Clin Nutr 2007;26(6):736-43.

[22] Le Bricon T, Gugins S, Cynober L, Baracos VE. Negative impact of cancer chemotherapy on protein metabolism in healthy and tumor-bearing rats. Metabolism 1995;44(10):1340-8.

[23] Vaisman N, Stallings VA, Chan H, Weitzman SS, Clarke RPP. Effect of chemotherapy on the energy and protein metabolism of children near the end of treatment for acute lymphoblastic leukemia. Am J Clin Nutr 1993:57(5):697-784.

[24] Deutz NEP, Thaden JJ, ten Have GAM, Walker DK, Engelen MPKJ. Metabolic phenotyping using kinetic measurements in young and older healthy adults. Metabolism [Internet] 2018 Jan 3;78:167-78 [cited 2017 Nov 26]. Available from: http://www.ncbi.nlm.nih.gov/pubmed/28986165.

[25] VanItallie TB, Yang MU, Heymsfield SB, Funk RC, Boileau RA. Heightnormalized indices of the body's fat-free mass and fat mass: potentially useful indicators of nutritional status. Am J Clin Nutr [Internet] 1990 Dec;52(6): 953-9 [cited 2017 May 9]. Available from: http://www.ncbi.nlm.nih.gov/ pubmed/2239792.

[26] ATS/ERS Statement on respiratory muscle testing. Am J Respir Crit Care Med 2002:66(4):518-624.

[27] Saey D, Debigaré R, LeBlanc P, Jeffery Mador M, Côté CH, Jobin J, et al. Contractile leg fatigue after cycle exercise: a factor limiting exercise in patients with chronic obstructive pulmonary disease. Am J Respir Crit Care Med 2003;168(4):425-30.

[28] Bohannon RW, Magasi SR, Bubela DJ, Wang Y-C, Gershon RC. Grip and Knee extension muscle strength reflect a common construct among adults. Muscle Nerve [Internet] 2012 Oct;46(4):555-8 [cited 2017 Nov 26]. Available from: http://www.ncbi.nlm.nih.gov/pubmed/22987697.

[29] Abumrad NN, Rabin D, Diamond MP, Lacy WW. Use of a heated superficial hand vein as an alternative site for the measurement of amino acid concentrations and for the study of glucose and alanine kinetics in man. Metabolism [Internet] 1981 Sep;30(9):936-40 [cited 2017 May 9]. Available from: http:// www.ncbi.nlm.nih.gov/pubmed/7022111.

[30] Washburn RA, Montoye HJ. The assessment of physical activity by questionnaire. Am J Epidemiol [Internet] 1986 Apr;123(4):563-76 [cited 2017 May 10]. Available from: http://www.ncbi.nlm.nih.gov/pubmed/3513548. 
[31] Granger CL, Parry SM, Denehy L. The self-reported Physical Activity Scale for the Elderly (PASE) is a valid and clinically applicable measure in lung cancer. Support Care Cancer [Internet] 2015 Nov 26;23(11):3211-8 [cited 2017 May 2]. Available from: http://link.springer.com/10.1007/s00520-015-2707-8.

[32] Karnofsky D, Burchenal J. The clinical evaluation of chemotherapeutic agents in cancer. In: MacLeod CM, editor. Evaluation of chemotherapeutic agents. New York: Columbia University Press; 1949. p. 191-205. The clinical evaluation of chemotherapeutic agents in cancer [Internet]. 1948. Available from: http://www.ncbi.nlm.nih.gov/pubmed/19403886.

[33] Yates JW, Chalmer B, McKegney FP. Evaluation of patients with advanced cancer using the Karnofsky performance status. Cancer [Internet] $1980 \mathrm{Apr}$ 15;45(8):2220-4 [cited 2017 May 11]. Available from: http://www.ncbi.nlm. nih.gov/pubmed/7370963.

[34] Aaronson NK, Ahmedzai S, Bergman B, Bullinger M, Cull A, Duez NJ, et al. The European Organization for Research and Treatment of Cancer QLQ-C30: a quality-of-life instrument for use in international clinical trials in oncology. J Natl Cancer Inst [Internet] 1993 Mar 3;85(5):365-76 [cited 2017 May 11] Available from: http://www.ncbi.nlm.nih.gov/pubmed/8433390.

[35] Engelen MPKJ, Com G, Anderson PJ, Deutz NEP. New stable isotope method to measure protein digestibility and response to pancreatic enzyme intake in cystic fibrosis. Clin Nutr [Internet] 2014 Dec;33(6):1024-32 [cited 2017 May 2]. Available from: http://linkinghub.elsevier.com/retrieve/pii/ S0261561413003051.

[36] Wolfe RR, Chinkes DL, Wolfe RR. Isotope tracers in metabolic research: principles and practice of kinetic analysis. Wiley-Liss; 2005. p. 474.

[37] Clarke JTR, Bier DM. The conversion of phenylalanine to tyrosine in man. Direct measurement by continuous intravenous tracer infusions of L-[ring2H5]phenylalanine and L-[1-13C]tyrosine in the postabsorptive state. Metabolism 1982;31(10):999-1005.

[38] Mason A, Engelen MPKJ, Ivanov I, Toffolo GM, Deutz NEP. A four-compartmen compartmental model to assess net whole body protein breakdown using pulse of phenylalanine and tyrosine stable isotopes in humans. Am J Physiol Endocrinol Metab [Internet] 2017 Jul 1;313(1):E63-74 [cited 2017 Nov 26]. Available from: http://www.ncbi.nlm.nih.gov/pubmed/28270442.

[39] Cruz-Jentoft AJ, Baeyens JP, Bauer JM, Boirie Y, Cederholm T, Landi F, et al. Sarcopenia: European consensus on definition and diagnosis. Age Ageing 2010;39(4):412-23.

[40] Bodyscan UK. Bodyscan data [Internet] [cited 2018 Apr 12]. Available from: https://www.bodyscanuk.com/bodyscan-data.html.

[41] Ballard FJ, Burgoyne JL, Tomas FMPJ. Growth hormone-induced changes in myofibrillar protein breakdown in hypopituitary children. Clin Sci 1983;64(3):315-20.

[42] Young VR, Munro HN. Ntau-methylhistidine (3-methylhistidine) and muscle protein turnover: an overview. Fed Proc [Internet] 1978;37(9):2291-300. Available from: http://www.ncbi.nlm.nih.gov/pubmed/350635.

[43] Maddocks M, Lewis M, Chauhan A, Manderson C, Hocknell J, Wilcock A. Randomized controlled pilot study of neuromuscular electrical stimulation of the quadriceps in patients with non-small cell lung cancer. J Pain Symptom Manage 2009;38(6):950-6.

[44] Neil-Sztramko SE, Kirkham AA, Hung SH, Niksirat N, Nishikawa K, Campbell KL. Aerobic capacity and upper limb strength are reduced in women diagnosed with breast cancer: a systematic review. J Physiother 2014;60(4):189-200.

[45] Elia M, Carter A, Bacon S, Winearls CG, Smith R. Clinical usefulness of urinary 3-methylhistidine excretion in indicating muscle protein breakdown. Br Med (Clin Res Ed) [Internet] 1981;282(6261):351-4. Available from: http://www. ncbi.nlm.nih.gov/pubmed/6780020\%5Cnhttp://www.pubmedcentral.nih.gov/ articlerender.fcgi?artid=PMC1504145
[46] Inoue Y, Miki C, Kusunoki M. Nutritional status and cytokine-related protein breakdown in elderly patients with gastrointestinal malignancies. J Surg Oncol [Internet] 2004 May 1;86(2):91-8 [cited 2017 Jun 24]. Available from: http://www.ncbi.nlm.nih.gov/pubmed/15112251.

[47] Neuhäuser M, Bergström J, Chao L, Holmström B, Nordlund L, Vinnars E, et al. Urinary excretion of 3-methylhistidine as an index of muscle protein catabolism in postoperative trauma: the effect of parenteral nutrition. Metabolism 1980;29(12):1206-13.

[48] Vissers YLJ, von Meyenfeldt MF, Argilés JM, Luiking YC, Dejong CHC, Deutz NEP. Protein breakdown on whole-body and organ level in noncachectic tumour-bearing mice undergoing surgery. Clin Nutr 2007;26(4): 483-90.

[49] Van Acker BA, Hulsewé KW, Wagenmakers AJ, Deutz NE, Van Kreel BK, Halliday D, et al. Absence of glutamine isotopic steady state: implications for the assessment of whole-body glutamine production rate. Clin Sci (Lond) [Internet] 1998;95(3):339-46. Available from: http://www.ncbi.nlm.nih.gov/ pubmed/9730854.

[50] Koopman R, Caldow MK, Ham DJ, Lynch GS. Glycine metabolism in skeletal muscle. Curr Opin Clin Nutr Metab Care [Internet] 2017 Jul;20(4):237-42 [cited 2017 Dec 21]. Available from: http://www.ncbi.nlm.nih.gov/pubmed/ 28375879.

[51] Spriet LL, Whitfield J. Taurine and skeletal muscle function. Curr Opin Clin Nutr Metab Care 2015:96-101.

[52] Lourenço R, Camilo ME. Taurine: a conditionally essential amino acid in humans? An overview in health and disease. Nutr Hosp 2002:262-70.

[53] Hébuterne $X$, Lemarié $E$, Michallet $M$, de Montreuil CB, Schneider SM, Goldwasser F. Prevalence of malnutrition and current use of nutrition support in patients with cancer. J Parenter Enteral Nutr [Internet] 2014;38(2): 196-204. Available from: http://www.ncbi.nlm.nih.gov/pubmed/24748626.

[54] Unsal D, Mentes B, Akmansu M, Uner A, Oguz M, Pak Y. Evaluation of nutritional status in cancer patients receiving radiotherapy: a prospective study. Am J Clin Oncol [Internet] 2006;29(2):183-8. Available from: http://www. ncbi.nlm.nih.gov/pubmed/16601440.

[55] Muscaritoli M, Lucia S, Farcomeni A, Lorusso V, Saracino V, Barone C et al. Prevalence of malnutrition in patients at first medical oncology visit: the PreMiO study. Oncotarget [Internet] 2017 Oct 2;8(45):79884-96 [cited 2017 Dec 21]. Available from: http:/www ncbi.nlm.nih gov/pubmed/29108370.

[56] Gioulbasanis I, Martin L, Baracos VE, Thézénas S, Koinis F, Senesse P. Nutritional assessment in overweight and obese patients with metastatic cancer: does it make sense? Ann Oncol [Internet] 2015 Jan;26(1):217-21 [cited 2017 Dec 21]. Available from: http://www.ncbi.nlm.nih.gov/pubmed/25361991.

[57] Prado CMM, Baracos VE, Xiao J, Birdsell L, Stuyckens K, Park YC, et al. The association between body composition and toxicities from the combination of Doxil and trabectedin in patients with advanced relapsed ovarian cancer. Appl Physiol Nutr Metab [Internet] 2014 Jun;39(6):693-8 [cited 2017 May 2]. Available from: http://www.nrcresearchpress.com/doi/abs/10.1139/apnm2013-0403.

[58] Kitagawa M, Haji S, Amagai T. High serum essential amino acids as a predictor of skeletal muscle depletion in patients with cachexia and advanced gastrointestinal cancers. Nutr Clin Pract 2017;32(5):645-51.

[59] Baracos VE. Skeletal muscle anabolism in patients with advanced cancer. Lancet Oncol [Internet] 2015 Jan;16(1):13-4 [cited 2017 Aug 14]. Available from: http://linkinghub.elsevier.com/retrieve/pii/S1470204514711854.

[60] Arends J, Bachmann P, Baracos V, Barthelemy N, Bertz H, Bozzetti F, et al. ESPEN guidelines on nutrition in cancer patients. Clin Nutr [Internet] 2017 Feb;36(1):11-48 [cited 2017 Jun 24]. Available from: http://linkinghub. elsevier.com/retrieve/pii/S0261561416301819. 